\title{
Morphological study of the relation between accidental hypothermia and acute pancreatitis
}

\author{
ALAN K FOULIS \\ From the Department of Pathology, Western Infirmary, Glasgow
}

SUMMARY There is a recognised but poorly understood association between hypothermia and acute pancreatitis. A histological study of the pancreas was made in eight patients with accidental hypothermia who had evidence of pancreatitis at necropsy. From an analysis of the patterns of parenchymal necrosis in the pancreas it was thought that there were at least three possible mechanisms for the relation between hypothermia and pancreatitis. Firstly, that ischaemic pancreatitis may result from the "microcirculatory shock" of hypothermia. Secondly, that both hypothermia and pancreatitis may be secondary to alcohol abuse; and finally, that severe pancreatitis may be the primary disease and that hypothermia results from the patients' social circumstances.

Acute pancreatitis is recognised to be a common finding in adult patients with accidental hypothermia. Between $50 \%$ and $65 \%$ of hypothermic patients have a raised serum amylase activity, and acute pancreatitis is found at necropsy in $20-30 \%$ of cases. $^{12}$ The mechanisms involved in this relation have remained obscure.

Recent work by the author has shown that at least two basic factors are involved in the initiation of acute pancreatitis, and that these can be recognised on histological examination of the pancreas. "Periductal" necrosis, where there is inflammation of pancreatic excretory ducts with inflammation and necrosis of surrounding parenchyma, was associated with pancreatitis secondary to gallstones, alcohol abuse and diabetes. "Perilobular" necrosis, where necrosis is confined to the microcirculatory periphery of the pancreatic exocrine lobule, was associated with pancreatitis occurring secondary to either septic or cardiogenic shock and was thought to represent ischaemic pancreatitis. While either of these patterns of necrosis can be found as the sole manifestation of pancreatitis, periductal necrosis may result in damage to adjacent vessels, which then thrombose. Such thrombosis will result in sludging in the microcirculation and thus perilobular necrosis. Therefore when both periductal and perilobular necrosis are found together periductal necrosis is presumed to represent the initial event.

This paper presents the clinical findings and patterns of pancreatic necrosis seen in eight patients with pancreatitis and accidental hypothermia. On the basis of these findings an attempt is made to explain the mechanisms involved in their relation.

Accepted for publication 11 May 1982

\section{Material and methods}

The necropsy records of the Western Infirmary and Southern General Hospital, Glasgow, over the last five years, were studied. Cases were selected where the patient had been admitted with a clinical diagnosis of hypothermia (rectal temperature less than $35^{\circ} \mathrm{C}$, using a low reading thermometer), where there was clinical and/or post mortem evidence of acute pancreatitis, and where advanced autolysis did not preclude adequate microscopic examination. Eight cases were suitable for study. Sections of pancreas were stained by haematoxylin and eosin and Martius scarlet blue.

\section{Results}

The results are summarised in Table 1. In only case 2 was a serum amylase estimation performed and a diagnosis of pancreatitis made antemortem.

Macroscopic pancreatitis was noted at necropsy in all but cases 5 and 6 . In case 8 there was widespread fat necrosis in the lesser and greater peritoneal sacs. Otherwise necrosis was confined to the immediate vicinity of the pancreas. The thyroid was normal macroscopically in all but case 3 where the thyroid was atrophic. In cases 5 and 8 histology was done which confirmed a normal thyroid morphology. Biochemical thyroid function tests were done in cases 1,2 and 3 . The former two were euthyroid and the latter hypothyroid.

In cases 1-5 perilobular necrosis of the pancreas was the only pattern observed (Fig 1). In cases 1 and 2 there was marked congestion and interstitial haemorrhage, maximal at the periphery of the lobules. This was 
Hypothermia and acute pancreatitis: clinico-pathological summary

\begin{tabular}{|c|c|c|c|c|c|c|c|c|c|}
\hline $\begin{array}{l}\text { Case } \\
\text { No }\end{array}$ & $\begin{array}{l}\text { Age (yr) } \\
\text { andsex }\end{array}$ & $\begin{array}{l}\text { Admission } \\
\text { temperature } \\
\left.{ }^{\circ} \mathrm{C}\right)\end{array}$ & $\begin{array}{l}\text { Admissiom } \\
\text { heart rate } \\
\text { (beats/min) }\end{array}$ & $\begin{array}{l}\text { Admissiom } \\
B P(m m H g)\end{array}$ & $\begin{array}{l}\text { Imerial } \\
\text { between } \\
\text { hypothermia } \\
\text { and death }\end{array}$ & $\begin{array}{l}\text { Possible } \\
\text { predisposing } \\
\text { factors for } \\
\text { hypolhermia }\end{array}$ & $\begin{array}{l}\text { Gallswomes } \\
\text { at mece(t)sy }\end{array}$ & $\begin{array}{l}\text { Patrernof } \\
\text { pancreatitis } \\
\text { necrosis }\end{array}$ & 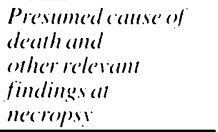 \\
\hline 1 & $85 \mathrm{M}$ & 26 & 40 & Unrecordable & 2 days & $\mathrm{Nil}$ & No & Perilobular & Bronchopncumonia \\
\hline 2 & $64 \mathrm{~F}$ & 27 & 62 & Unrecordable & 2 days & $\begin{array}{l}\text { Alcohol } \\
\text { abuse }\end{array}$ & No) & Perilobular & Bronchopncumonia \\
\hline 3 & $80 \mathrm{~F}$ & 34 & 58 & $70 / 50$ & $2 w k s$ & Myxoedema & Yes & Perilobular & $\begin{array}{l}\text { Coronary thrombosis } \\
\text { and myocardial } \\
\text { infarction }\end{array}$ \\
\hline 4 & $69 \mathrm{~F}$ & 32 & 60 & $110 / 70$ & $2 w k s$ & $\begin{array}{l}\text { Parkinson: } \\
\text { discase }\end{array}$ & No & Perilobular & $\begin{array}{l}\text { Boundary zone } \\
\text { cerebral infarct } \\
\text { approx two weehs } \\
\text { duration }\end{array}$ \\
\hline 5 & $79 \mathrm{~F}$ & 28 & 60 & Unrecordable & 5 days & Nil & No & Perilobular & Bronchopncumonia \\
\hline 6 & $56 \mathrm{M}$ & 34 & Not known & Notknown & 2 days & $\begin{array}{l}\text { Alcohol } \\
\text { abuse }\end{array}$ & No & Periductal & $\begin{array}{l}\text { Myocardial } \\
\text { intarction. Small } \\
\text { bowel infarction }\end{array}$ \\
\hline 7 & $51 \mathrm{M}$ & 29 & 60 & Unrecordable & I day & $\begin{array}{l}\text { Alcohol } \\
\text { abuse }\end{array}$ & No & $\begin{array}{l}\text { Perilobular and } \\
\text { periductal }\end{array}$ & $\begin{array}{l}\text { Peripheral vascular } \\
\text { disease }\end{array}$ \\
\hline 8 & $88 \mathrm{~F}$ & 32 & 120 & Unrecordable & 2 days & Nil & Yes & $\begin{array}{l}\text { Perilobular and } \\
\text { periductal }\end{array}$ & Pulmonary comboli \\
\hline
\end{tabular}

associated with fibrin deposition both within capillaries and in their immediate vicinity (inset at higher magnification). In cases 3 and 4 there was evidence of organisation of the necrotic pancreatic parenchyma at the lobular periphery. Cases 6,7 and 8 had periductal necrosis associated with marked duct inflammation (Fig 2). Significant perilobular necrosis was also seen in cases 7 and 8.

Several clinical factors were present which can be associated with the development of pancreatitis. Gallstones, confined to the gallbladder, were present in two patients. Three patients were known to be chronic alcoholics and six patients were shown to be hypotensive on admission. Five patients had been prescribed drugs prior to admission. Cases 5 and 8 were taking frusemide, case 1 cyclopenthiazide, case 3 bendrofluazide and case 4 orphenadrine hydrochloride.

\section{Discussion}

Perilobular necrosis, when it is the sole pattern of parenchymal necrosis has been shown previously to represent ischaemic pancreatitis. ${ }^{3}$ The patients in that study had a high incidence of systemic hypotension and four of the five patients in this study who had only perilobular necrosis were hypotensive on admission. The fifth patient (case 4) had an admission blood pressure of $110 / 70 \mathrm{mmHg}$. However she was a known hypertensive, who at a recent admission had a blood pressure of 190/105 $\mathrm{mmHg}$. Thus all five patients had relative hypotension.

It has been argued that the changes in the microcirculation during hypothermia resemble those in shock, and consist of a loss of microcirculatory control with hypoperfusion. ${ }^{4}$ In severe hypothermia local accumulation of metabolites and hypoxia in the microcirculation result in loss of arteriolar and precapillary sphincter tone. The venous side of the microcirculation is thought to be less susceptible to these factors and thus the capillaries become engorged with stagnant blood and the patient develops hypotension. Fluid and red cells leak out of the circulation when the capillary endothelium is damaged by hypoxia. This results in the tissue appearance of engorged capillaries, haemorrhage into the interstitial space and intra and extra vascular coagulation. This was exactly the appearance seen in the periphery of the pancreatic lobules in patients one and two who both died within two days of the hypothermic episode. Thus it appears that in the first five patients, who had only perilobular necrosis, with no evidence of duct inflammation, the pancreatitis was secondary to the "microcirculatory shock" of primary hypothermia. It could be argued that case 2 was alcoholic and case 3 had gallstones and that these could be the causes of the pancreatitis. However, previous studies have shown no association between perilobular necrosis as the sole form of pancreatitis and these causes of pancreatitis. ${ }^{3}$

Ischaemic damage to the pancreas as a result of hypothermia has been previously suggested as a cause of pancreatitis. Two case reports suggested that hypothermia had caused intravascular coagulation and that this had precipitated ischaemic pancreatitis. The patient studied by Savides and Hoffbrand ${ }^{5}$ had thrombosis of the superior pancreatico-duodenal vein and intrapancreatic veins, in addition to infarction of areas of the gallbladder. duodenum and both adrenals. The second patient. reported by Mahood and Evans ${ }^{6}$ had both haematological and post mortem evidence of disseminated intravascular coagulation (DIC). Neither patient was hypetensive on admission. Activation of the coagulation system is a recognised occurrence in patients with accidental hypothermia, ${ }^{7}$ but DIC is also a recognised complication of acute pancreatitis. ${ }^{8}$ Thus it is difficult to decide whether pancreatitis or hypothermia caused the intravascular coagulation. The finding of pancreatic duct inflammation reported in Savides and Hoffbrand's patient 


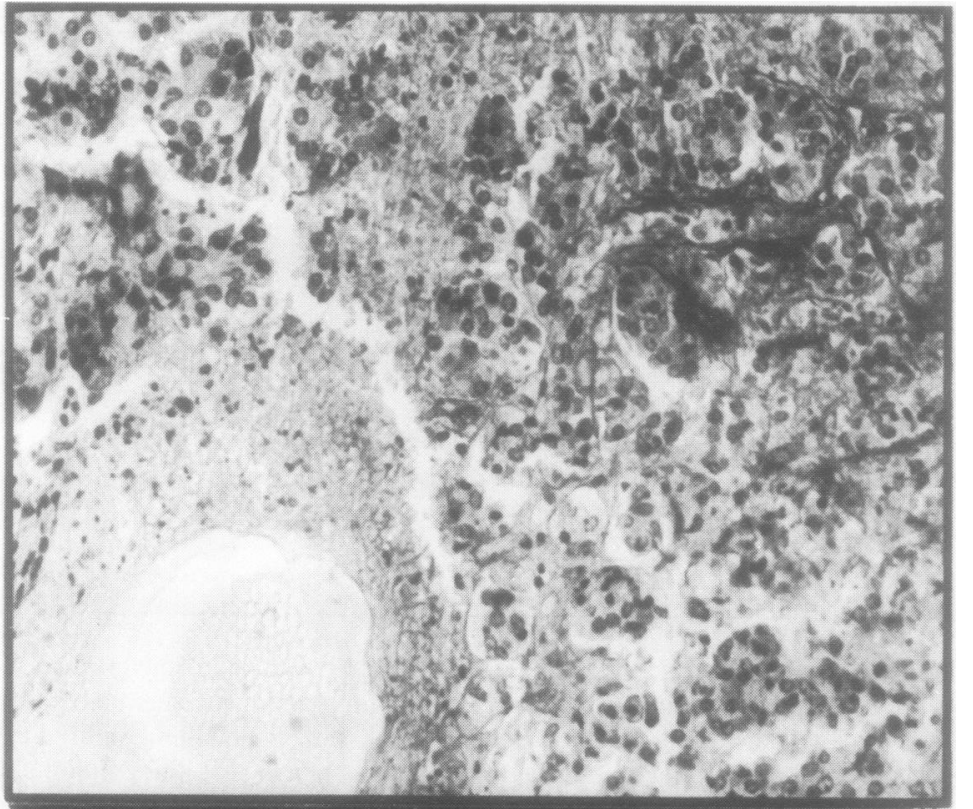

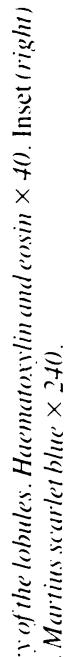

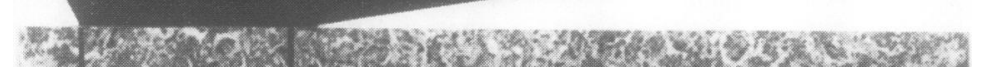
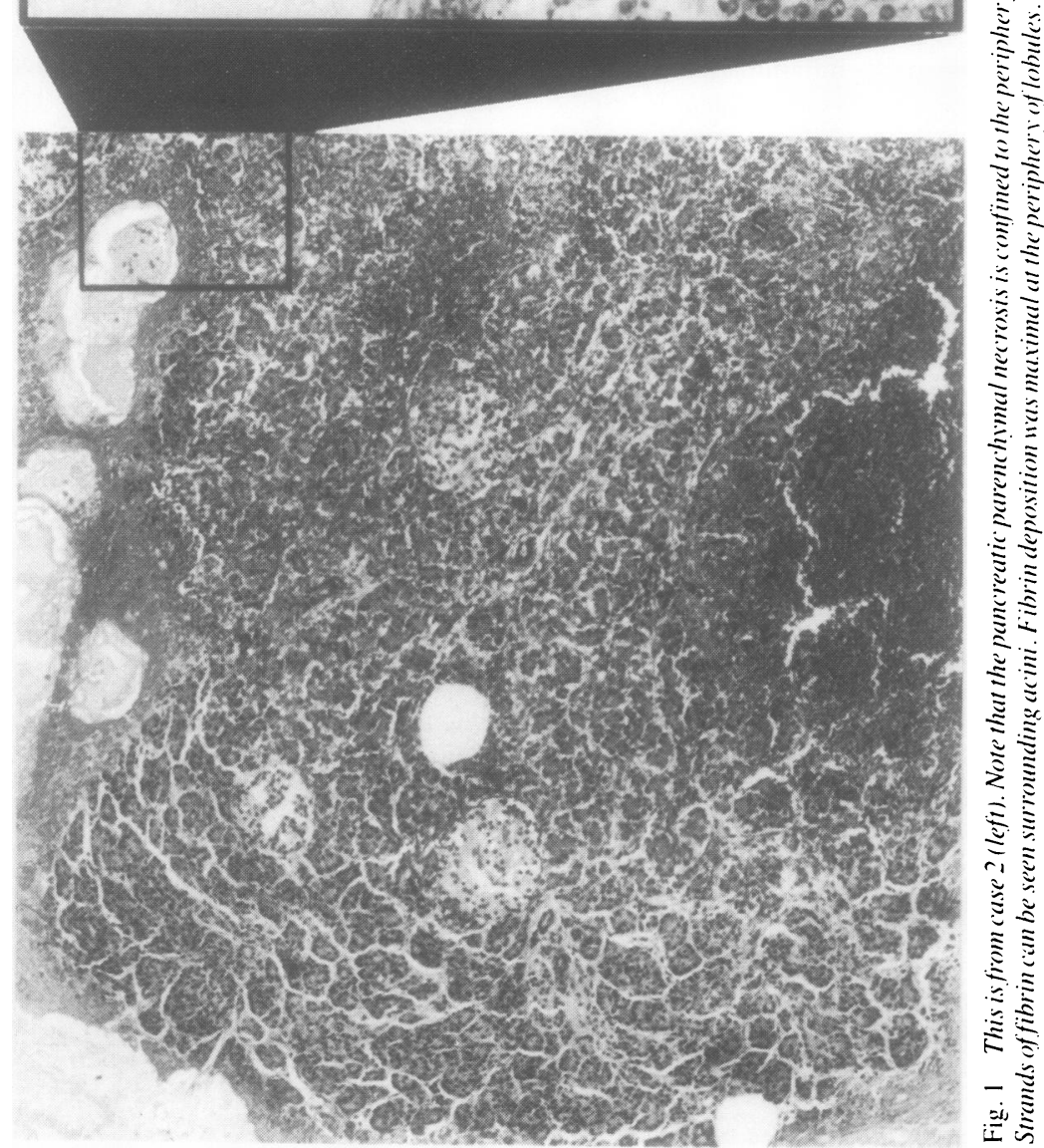


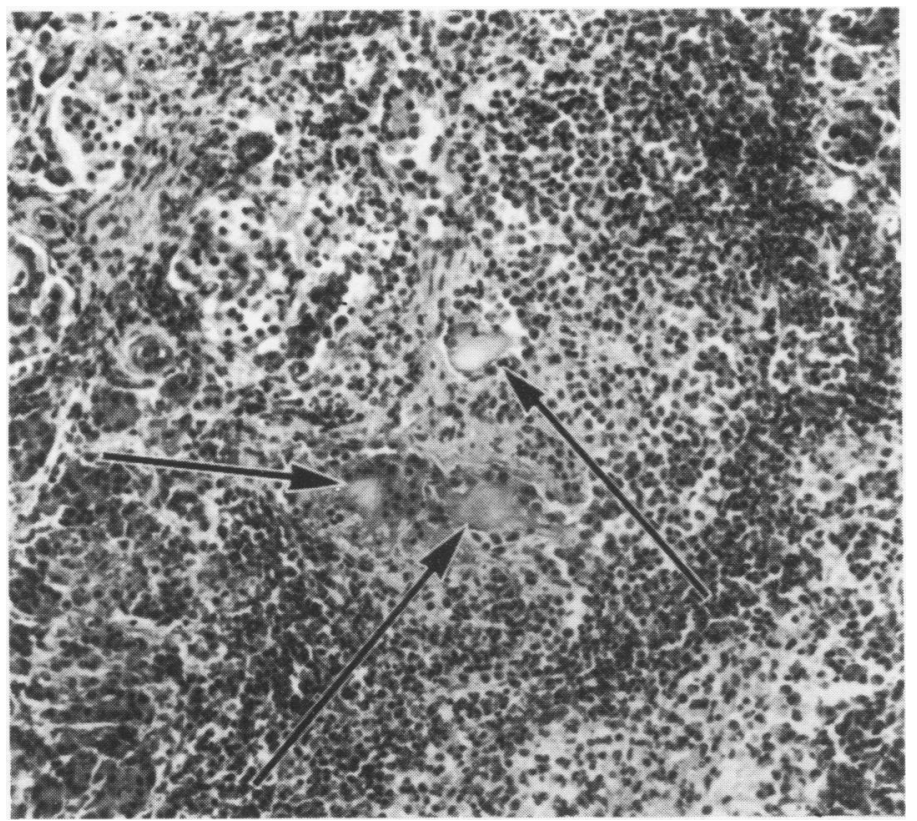

Fig. 2 This is from case 8. Inflamed intralobular ducts containing proteinaceous concretions are marked by arrow's. There is surrounding periductal inflammation and necrosis. Haematorylin and eosin $\times 150$.

would be unusual in an ischaemic pancreatitis and might suggest that pancreatitis was the initial event. Similarly, in Mahood and Evans' report, where no details of the pancreatic morphology are given, the patient was an alcoholic who could have developed primary alcoholic pancreatitis. Thus in both cases the exact sequence of events is still in doubt.

Cases 6, 7 and 8 had duct inflammation and periductal necrosis. This form of pancreatitis has been associated with alcohol abuse or the presence of gallstones. Both cases 6 and 7 were alcoholic and case 8 had gallstones. Chronic alcoholism predisposes a patient to accidental hypothermia ${ }^{9}$ and it may be that in case 6 , who had only microscopic pancreatitis, with no evidence of perilobular necrosis, both hypothermia and pancreatitis were secondary to alcohol abuse. Case 8 had the most extensive pancreatitis of the group. On admission she was noted to have a distended silent abdomen and a tachycardia. The histological appearance of widespread periductal necrosis is entirely consistent with a gallstone aetiology for the pancreatitis and is not seen in pancreatitis secondary to shock. Thus here it is likely that the patient had primary gallstone pancreatitis and developed hypothermia as a result of exposure (she lived alone and was found unconscious on the floor of her flat). In case 7 the presence of duct inflammation and periductal necrosis is strongly suggestive of an alcoholic aetiology for the pancreatitis. Whether the hypothermia was secondary to alcohol abuse as suggested in case 6 , or pancreatitis as suggested in case 8 remains a moot point.

Four of the patients studied were receiving diuretics.
By 1977 pancreatitis had been reported in 16 patients treated with these drugs in whom no other cause for the pancreatitis was apparent. ${ }^{10}$ Considering the high prevalence of diuretic usage this is obviously a very rare association, and a causal role for diuretics has not yet been fully established. In the present study other predisposing factors were present which correlated with the morphological appearances in the pancreas, so a drug aetiology for the pancreatitis seems unlikely.

\section{Conclusion}

Three possible mechanisms for the relation between accidental hypothermia and pancreatitis in this series are proposed. In cases $1-5$ hypothermia appears to have been primary. They have developed the "microcirculatory shock" of hypothermia, which has resulted in ischaemic pancreatitis. In case 6 both the pancreatitis and hypothermia appear to have been the result of alcohol abuse, and in case 8 it seems likely that hypothermia developed secondary to primary gallstone pancreatitis. It will require a larger series based on these lines to determine the relative frequencies of these various mechanisms in the relation between accidental hypothermia and acute pancreatitis.

I am indebted to Mr Graham Reid and Mr John Hendry for expert technical help. 
References

' Maclean D. Murison J. Griffiths PD. Acute pancreatitis and diabetic ketoacidosis in accidental hypothermia and hypothermic myxoedema. Br Med J 1973:4:757-61.

2 Duguid H, Simpson RG. Stowers JM. Accidental hypothermia. Lancet 1961:ii: 1213-9.

${ }^{3}$ Foulis AK. Histological evidence of initiating factors in acute pancreatitis in man. J Clin Pathol 1980:33:1125-31.

+ Maclean D. Emslie-Smith D. Accidental hypothermia Oxford: Blackwell Scientific Publications, 1977:126-30.

${ }^{5}$ Savides EP, Hoffbrand BI. Hypothermia. thrombosis and acute pancreatitis. Br Med J 1974:i:614.
'Mahood JM, Evans A. Accidential hypothermia, disseminated intravascular coagulation and pancreatitis. NZ Med J 1978:87:283-4.

${ }^{7}$ Goodhall HB, Todd AS, Maclean D, Henderson R, King JF. Cryofibrinogenaemia and activation of the coagulation /lysis systems in accidental hypothermia in the elderly. J Clin Pathol 1975;28:758

${ }^{8}$ Kwaan, HC, Anderson MC, Gramatica L. A study of pancreatic enzymes as a factor in the pathogenesis of disseminated intravascular coagulation during acute pancreatitis. Surgery 1971;69:663-72.

${ }^{9}$ Maclean D, Emslie-Smith D. Accidental hypothermia Oxford: Blackwell Scientific Publications, 1977:275.

${ }^{10}$ Nakashima Y. Howard JM. Drug induced acute pancreatitis. Surg Gynecol Obstet 1977:145:105-9.

\section{The October 1982 issue}

\section{THE OCTOBER 1982 ISSUE CONTAINS THE FOLLOWING PAPERS}

\section{Review Article}

Some aspects of the metastatic process RL CARTER

Value of external quality assessment of the technical aspects of histopathology WT BARR, ED WILLIAMS

Morphometric study of liver cell nuclei in hepatomas using an interactive computer technique: (i) nuclear size and shape R JAGOE, C SOWTER, SHEILA DANDY, G SLAVIN

Morphometrical analysis of urothelial cells in voided urine of patients with low grade and high grade bladder tumours ECM OOMS, PJH KURVER, MATHILDE E BOON

A quantitative study of $\alpha$-naphthyl acetate esterasepositive cells in non-Hodgkin's lymphomas and reactive lymph nodes J CROCKER, EL JONES, RC CURRAN

Wilms' tumour and renal dysplasia: an hypothesis HB MARSDEN, W LAWLER

Unusual subcutaneous mixed tumour exhibiting adipose, fibroblastic, and epithelial components PS SMITH, J MCCLURE

Micronodular adrenal disease: a light and electron microscopic study PS HASLETON, HH ALI, C ANFIELD, CG BEARDWELL, S SHALET

6-Thioguanine as a cause of toxic veno-occlusive disease of the liver MB SATTI, K WEINBREN, EC GORDON-SMITH

Improved double immunoenzyme labelling using alkaline phosphatase and horseradish peroxidase NJMALIK, ME DAYMON

Guidelines for the evaluation of instruments used in haematology laboratories NK SHINTON, JM ENGLAND, DA KENNEDY

A new case of congenital dyserythropoietic anaemia, type III: studies of the cell cycle distribution and ultrastructure of erythroblasts and of nucleic acid synthesis in marrow cells SN WICKRAMASINGHE, TE PARRY, C WILLIAMS, AN BOND, MADELEINE HUGHES, SALLY CROOK

Assessment of a radioisotopic assay for vitamin $B_{12}$ using an intrinsic factor preparation with $\mathbf{R}$ proteins blocked by vitamin $B_{12}$ analogues BARBARA BAIN, GN BROOM, JACKIE WOODSIDE, RA LITWINZUK, SN WICKRAMASINGHE
Three step purification of Clq by DNA precipitation, ion exchange and lectin affinity chromatography M RHEN, E LINDER

Antinuclear antibody - negative systemic lupus erythematosus - how common? KC McHARDY, CHW HORNE, JAN RENNIE

Development and evaluation of an enzyme-linked immunosorbent assay (ELISA), using chlamydial group antigen, to detect antibodies to Chlamydia trachomatis RT EVANS, D TAYLOR-ROBINSON

Enzyme-linked immunosorbent assay (ELISA) for detection of specific IgA antibodies to mumps virus B HALEVY? I SAROV

Rapid enzyme-linked immunosorbent assay (ELISA) for Aspergillus fumigatus antibodies MD RICHARDSON JUDITH M STUBBINS, DW WARNOCK

Detection of antibodies to tetanus toxoid: comparison of a direct haemagglutination method with a radioimmunoassay AS WANG, GF BURNS, IJ KRONBORG, IR MACKAY

Comparison of a homemade blood culture broth containing a papain digest of liver, with four commercially available media for the isolation of anaerobes from simulated paediatric blood cultures GH HUNT, ELIZABETH H PRICE

Reciprocal antimicrobial synergism between Escherichia coli and Bacteroides fragilis in the presence of metronidazole F SORIANO, MC PONTE, MC GASPAR

Acquisition of new genes by oral Neisseria CATHERINE ISON, AA GLYNN, SHOSHANA BASCOMB

The use of an anaerobic incubator for the isolation of anaerobes from clinical samples PLBERRY, ETAYLOR, I PHILLIPS

\section{Technical method}

Histological localisation of mammographic abnormalities in breast biopsy specimens GWH STAMP, IW McDICKEN, GH WHITEHOUSE

\section{Letters to the Editor}

Book reviews

Notices 